Northern Ireland. Recognising that commercial publishers cannot operate successfully in a jurisdiction with a population of $1 \frac{1}{2}$ million, the local professional bodies and the responsible government department, together with the Nuffield Foundation, have collectively given the Faculty of Law in the Queen's University of Belfast an annual grant of approximately $£ 35,000$ for five years. This grant will finance a programme of legal publications under the collective title of "Servicing the Legal System". With the aid of an Advisory Committee representing the various legal interests in the province, the Faculty will organise the research, writing and publication of texts on various aspects of Northern Ireland Law. In particular, a monthly Bulletin summarising all current legal developments in the province is being published (from February 1981) to provide a practical complement to the existing Northern Ireland Legal Quarterly. Other publications, some of which have already begun to appear, will range from practice notes to full-scale texts.

Full details of the Programme, and of SLS publications, are available from Professor Desmond Greer, Faculty of Law, Queen's University, Belfast BT7 1NN, Northern Ireland.

\title{
THREE LATIN AMERICAN LEGAL PERIODICALS OF INTERNATIONAL INTEREST
}

Derecho Comparado; Revista de la Asociación Argentina de Derecho Comparado. Buenos Aires, Argentina, Victor P. de Zavalía, Editor. (Alberti 835, Buenos Aires). 1977.

This is a legal periodical published in Spanish with summaries in French and English appended to the major articles. Its first issue appeared in 1977 coinciding with the 30th anniversary of the Asociacion Argentina de Derecho Comparado (Argentinian Association of Comparative Law) as its official organ. Intended to meet the demand for publications of this kind in the area of comparative law in Latin America, its publishers main purposes are: a) to give world-wide information including research articles concerning recent legal developments from a comparative approach, and b) to spread outside of Argentine the scientific work of Argentinian comparativists. In order to accomplish this task the editors not only include original collaborations of Argentinian jurists but also translations of foreign authors as well.

Each book is organized as follows: a) leading articles in Spanish, either originals or translated from foreign languages followed by summaries in French and English, b) comments on narrow topics of the law, c) bibliography (book reviews), d) review of reviews (reviews of legal periodicals), e) books received (a listing) and $f$ ) report of activities of 
AADC. Programmed to appear twice a year, three issues have been already published and a fourth one is on the way.

The topics covered through the different issues are varied. Each number covers a different area. The first volume was devoted to "legal regulation of civil liability in private law." The second volume approached the question of "constitutional and social clauses." The third volume dealt with "problems of contemporary penal law":, and the fourth will treat the "legal aspects of the international activties of the public corporation."

The authorship of the articles and comments is impressive. Not only the elite of the Argentinian jurists collaborate here but also reknown comparativists of Latin America, Europe and the U.S.A. Some of the members of the editorial board are bringing to this endeavor their previous experience in the prestigious Revista Juridica de la Universidad de Buenos Aires-no longer published, and they count with a prestigious "Comité de Patronage" where a multiciplicity of nations are represented.

Just selecting at random some of the most outstanding contributions it called to our attention a very interesting article on "The New Frontiers in Civil Liability", by Jorge Mosset Iturraspe, whose almost poetic style sharply contrasts with the dry prose usually found in legal writing. It was also noticed a short but very relevant article by the famous penologist Sebastian Soler under the title "Objective Structures and Legal Types" where some recent Natural Law doctrines are discussed on their application to Criminal Law. It is also an important contribution the article of "Problems of the Victim in Penal Law and in Modern Criminal Policy" by the reputable French jurist Marc Ancel, who advocates the enactment of legislation that will provide victims with thorough information about their rights and the means to exercise them in court.

We are in the presence of an outstanding periodical in the area of comparative law. In going through its different issues the reviewer feels very well impressed with the background of the authors who collaborate, the relevancy of the topics selected, the high degree of scholarship of the presentations and the accuracy of the translations. This title should be added to the collection of all law libraries regardless of the language their patrons command. It is too important to be set aside. It also carries a message for the general practitioner interested in more expanded horizons than that of its local jurisdiction.

Revista del Instituto de Derecho del Trabajo e Investigaciones Socrales. Quito, Ecuador, Universidad Central del Ecuador Facultad de Jurisprudencia, Ciencias Politicas y Sociales. 1965.

This is a semi-annual publication that first appeared in 1965 and of which twenty issues have already been published-some of them consolidated in one volume. It is entirely written in Spanish and primarily devoted to labor law. 
The issue we had at hand, number 21-22 includes seven leading articles on: the contract for personal services, stability in the job and comparative law, freedom of unionization, social security, the working day in the "Grupo Andino", procedural aspects of labor law, and the termination of the employer-employee relationship. It also includes a comprehensive survey of the Ecuadorian labor legislation in 1975 and the by-laws of the Asociación Ibero-Americana de Derecho del Trabajo (IberoAmerican Association of Labor Law).

A special feature is the inclusion of a section called "Jurisprudencia" which consists of a set of $6.5^{\prime \prime} \times 5^{\prime \prime}$ cards, each card containing a brief summary of important decisions of Eucadorian courts in the area of labor law. These cards can be detached from the book and collected by any kind of rational order. Labor law is taking a place of prominence in the general body of law all around the world. Publications of this kind, once considered narrow in scope now are important items that the librarian should not overlook. Latin American publications in this area are also attaining a position of relevancy with the creation of the "Grupo Andino" which probably will equal in the future the scope of the European Economic Community.

The editors of this publication as well as its collaborators are distinguished law professors, jurists and practitioners who give the review the necessary credibility of a scholarly work. Its shortcomings are present in the facts that it is all written in Spanish and it emphasizes Ecuadorian laws although some attention is paid to comparative law. However, it is an item not to be overlooked by those who have the aspiration of creating a comprehensive collection on labor law. The editors have extended an open invitation for collaboration from foreign authors and they are interested in exchanges. Details might be found by writing to: Dirección para Canjes, Instituto de Derecho del Trabajo e Investigaciones Sociales, Facultad de Jurisprudencia, Ciencias Políticas y Sociales, Universidad Central del Ecuador, Quito, Ecuador, S.A.

Jurisprudencia del Trabajo Anotada. Buenos Aires, Argentina, Victor P. de Zavalía, Editor. 1979.

This is a new periodical publication that appeared in Argentina in April 1979, and of which three volumes have already been published. It reports, with annotations selected opinions of Argentinian courts in the area of labor. Although it includes decisions of all the different courts throughout the nation, it devotes special attention to those rendered by the courts of the provinces of Buenos Aires, Córdoba and Santa Fé. The opinions appear verbatim. They are introduced by two or three headings that identify the specific area of labor law they deal with and by headnotes or syllabi which number vary according to the complexity of the issues confronted. Each opinion is followed by a commentary or an in-depth analysis written and signed by members of the editorial board. Each 
volume includes a section called "Reseñas de Jurisprudencia", which is a collection of abstracts of different decisions grouped under the common denominator of some specific, narrow aspect of labor law, e.g. "Confession as Evidence," "Documentary Evidence", etc.

This publication which is entirely written in Spanish is projected to appear five times a year and three issues have been already published. A cumulated, bound volume is supposed to appear at the end of each year. This cumulative volume will include parties, subject and jurisdiction indexes.

Considering the growing importance of labor law, these reports offer the opportunity of access to a body of case law that should be of extraordinary value not only to the scholar and the comparativist but also to the specialized practitioner as well. It should also be welcome in those libraries that serve a clientele capable of reading this material in its original language.

\author{
Jorge L. Carro \\ Professor of Law and Law Librarian \\ University of Cincinnati
}

\title{
DUTCH LAW LIBRARY BULLETIN
}

The inaugural issue of De Juridische Bibliothecaris (the Information Bulletin of the Dutch Group of Law Libraries and Legal Documentation Centers) was noted in the IALL Newsletter, No. 24, p. 2 (November 1979). In the meantime this new bulletin has commenced regular publication, and several issues have already made their appearance.

Each issue contains several short articles on different subjects pertaining to law librarianship and the retrieval of legal information, reports about the activities of Dutch law librarians, and extensive bibliographic lists of new publications. These lists should be useful to law librarians throughout the world. Meticulously compiled, they include not only references to new Dutch law books, but also to legal bibliographies published either in periodicals or as separate monographs in other countries. Articles and books on law librarianship are also listed irrespective of their place of publication. The lists are current and remarkably comprehensive. It is evident that the Dutch law librarians are well-informed about what gets published outside their country.

The editor-in-chief of De Juridische Bibliothecaris is Gert W. Vlasman, Law Librarian at the Catholic University in Tilsburg and an active member of the International Association of Law Libraries. Though the language of the publication is Dutch, it should present no difficulties to readers familiar with the English language. Two issues a year are published at the present time. The annual subscription is Dfl. 30. Subscriptions should be addressed to Mr. Gert W. Vlasman, Juridische Faculteit K. H. Tilburg, 5037 GC Tilburg, The Netherlands. 